\title{
Photovoltaic Prickle Pear Harvesting Tool
}

\section{Federico Hahn}

Departamento Irrigación, Universidad Autónoma Chapingo, Chapingo, México.

Email: fhahn@correo.chapingo.mx

Received February $9^{\text {th }}, 2013$; revised May $2^{\text {nd }}, 2013$; accepted May $21^{\text {st }}, 2013$

Copyright (C) 2013 Federico Hahn. This is an open access article distributed under the Creative Commons Attribution License, which permits unrestricted use, distribution, and reproduction in any medium, provided the original work is properly cited.

\begin{abstract}
Mexico is the largest cactus exporter of the world and $40 \%$ of the production cost is provided from the harvest operation. Many workers are required to operate daily and suffer wrist pain after two weeks of collecting pears with mechanical pruners. A motor driven tool supplied from a photovoltaic system was employed for harvesting; different blades were tested at different cutting speeds. It was found that toothed blades sliced the pears with efficiencies over $90 \%$. Abrasive blades were finally selected as the current required per cut was minimum, permitting a longer battery lifetime before requiring recharging.
\end{abstract}

Keywords: Prickle Pear; Harvesting Tool; Current Integral

\section{Introduction}

This Cactus pear (Opuntia sp.) is rich in vitamin $\mathrm{C}$ and proteins, low in fat with high calcium, phosphorus and iron content. Yellow cactus pear is rich in betalanins which are used by the food industry as colorants and for human stress control. Domestic per capita consumption of the fruit, harvested between July and September, increased from 2.15 to $3.75 \mathrm{~kg} /$ year between 1991 and 1997 [1]. The pulp juice can be dehydrated to obtain products such as cactus pear honey, cheese and "melcocha" [2]. These characteristics give cactus pear great possibilities for the export market.

Several species of prickly pear were domesticated in Mexico, which is the largest cactus pear producer with $79.4 \%$ of the world production, covering 49,165 ha [3] followed by Italy and South Africa with $12.2 \%$ and $3.7 \%$ of the production, respectively. However, competition for the export market is intense, and Italy is now the world's largest exporter, while Mexico exported 3374 million to the European Community in 1998-2001 [1]. Exporting cactus pear requires observance of high quality standards.

Analysis has shown that $37 \%$ of the workers using scissors maintain manual night parenthesis for twelve months, and $12 \%$ of the workers showed wrist pain during the same period [4]. Actually electric cutters are replacing scissors or mechanical cutters in developed countries; however their high costs over 1500 US remain the main concern for substituting mechanical cutters. Felco 800 [5] is an electrical $150 \mathrm{~W}$ cutter that uses a rechargeable Li-Ion rechargeable battery of $4 \mathrm{~A} / \mathrm{hr}$. The cutter can slice branches up to $30 \mathrm{~mm}$, being the battery life of 5 hours. The equipment weights $820 \mathrm{~g}$ and the battery weights $1.8 \mathrm{~kg}$. Electrical scissors cut $20 \%$ quicker and avoid hand muscular-skeleton disorders having a 10,000 US medical cure.

The following paper compares the energy consumption of a photovoltaic driven prickle pear harvesting tool, determining optimum blade and speed during fruit slicing. A data-logger monitored the current being used per cut, allowing to know which is the optimum blade that should be used.

\section{Materials and Methods}

A steel circular blade was used for cutting, and it was coupled to the motor aluminum shaft, Figure 1(a). Three different blades were tested at four different speeds 200, 500, 700 and 1000 RPM. The first steel circular blade was completely plane presenting no teeth, the second one presented 4 teeth per inch, while the third one 8 teeth per inch. The motor speed was varied with a $(\bmod$ Bronco II, Warner Electric, USA) DC speed drive using $110 \mathrm{~V}$ AC as voltage supply; the motor speed varied up to 3000 RPM. The first experiment considered cutting 100 nopal branches with each blade; an efficient cut was the one that did not left any cutting residues at the pears resulting from branch slashing. 
The $15 \mathrm{~cm}$-diameter stainless steel circular plane blade has a single cutting edge for better efficiency, during its operation. When the blade was sharpened in both edges it became brittle and the spines damaged it in quickly having an operational life of one day. The blade requires of teeth to cut more efficiently.

A data-logger (mod LabPro, VERNIER, USA) was connected measuring the current passing through the motor during prickle pear slicing to compare its consumption. A $1.26 \Omega-10 \mathrm{~W}$ resistance was connected between the power supply and the motor of the harvesting tool. The data-logger measured the voltage obtained in both sides of the resistance. For this experiment three different cutting blades were used: a music CD (compact disc), a toothless stainless steel blade and an abrasive cutting blade; this abrasive blade is the one commonly used for cutting metal and is $3 \mathrm{~mm}$ thick. Ten similar sized pears were sliced with a different blade and the values were averaged. Once the parameters of prickle pear harvesting tool were obtained it was tested in the field being supplied from a $10 \mathrm{~W}$ solar cell-50 Ah battery kit; the cell was fixed to a hat, Figure 1(b).

\section{Results and Discussion}

A prickle pear being harvested can be seen at Figure 2(a). The starting current (Figure 2(b)) is higher than the stopping current, Figure 2(c). As the speed of the motor tool increases, the cutting efficiency increased. Images from each cut indicated whether slashes occur or whether it was a perfect clean cut.

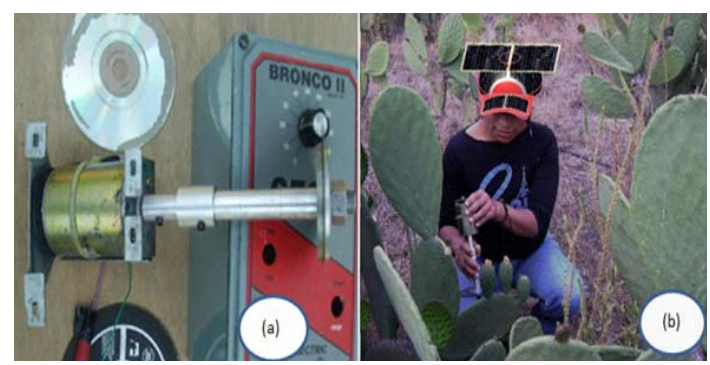

Figure 1. Harvesting tool (a) showing its components and (b) during operation.

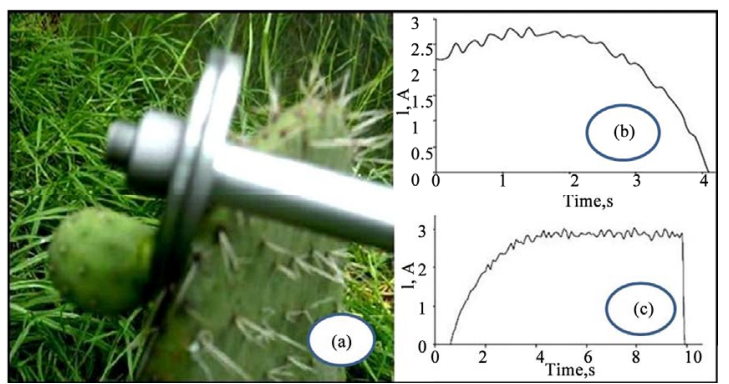

Figure 2. Tool (a) at harvest; (b) starting current and (c) stopping current.
A poor cut operation lasted over 4 minutes resulting from a poor sharpened blade. Toothed blades presented efficiencies over $90 \%$ at the four tested speeds. Table 1 Sonawane [6] reported that the cutter plate speed increased the effective capacity of a banana slicer, although the slicing efficiency decreased as the cutter speed increased.

The current measured by the data-logger shows different forms according to the blade employed during the cut. All of them sliced the fruit at the flat part of the curve at $7.9 \mathrm{~A}$, but the time required was different for each blade.

The null sharpening of the CD causes that the cut is longer, Table 2; the current integral becomes the highest as seen by the dotted line of Figure 3. The motor speed was increased but the cutting performance of the $\mathrm{CD}$ blade was still poor and at a speed over 800 RPM the CD break down in pieces. Also, CD blades could only be used ten times before showing scratching symptoms at its surface.

The shortest current achieved was the one obtained by the abrasive blade. As all the equipment that uses abrasive blades for cutting metal, they perform best at speeds over 1800 RPM; considering that vegetable tissues are softer a lower speed of 1000 RPM was employed. When the motor speed is lower than 100 RPM the sliced pear shows slashing tissue. A microscopic image (40X) of the tissue damage caused by abrasion at 300 and 900 RPM are shown in Figure 4; the lower speed causes cell burning meanwhile at a higher speed the tissue get burnt but without water pulp leaking. The higher speed cut permits a longer prickle pear shelf life.

Rotary cutters are the only flexible one among cutting tools showing good access to different parts of uneven surfaces [7]. A cutting and grinding machine that uses abrasive disks has been patented [8]; abrasive disks are mainly used for peeling. This application used the abrasive for cutting with high efficiency.

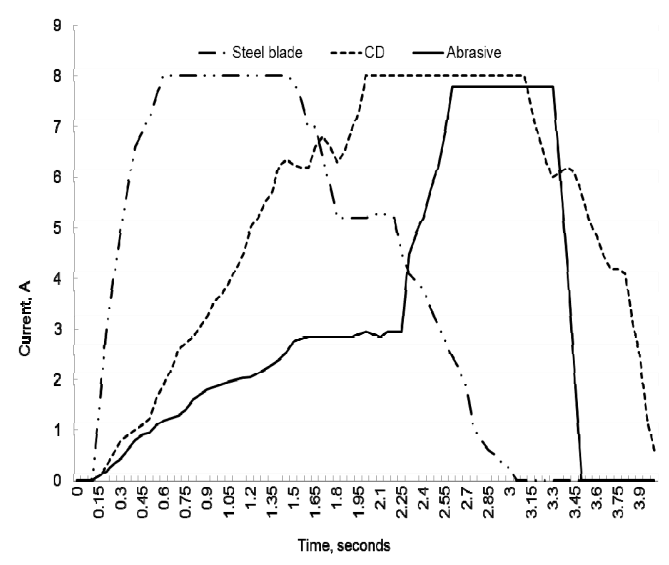

Figure 3. Current measured with a steel blade, a CD and an abrasive blade. 


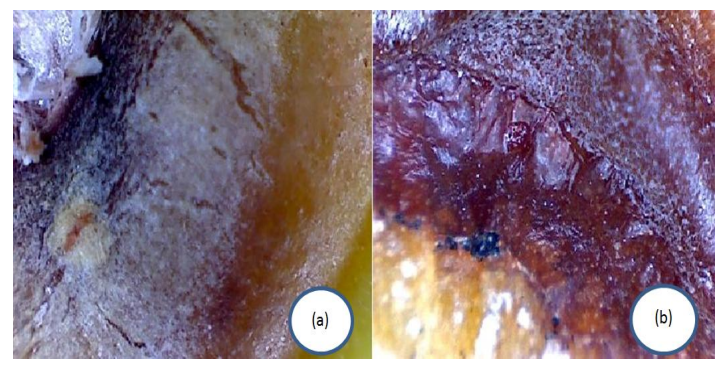

Figure 4. Microscopic image of an abrasive cut at 300 RPM and 900 RPM.

Table 1. Comparison of the cutting efficiency of plane and toothed blades.

\begin{tabular}{cccc}
\hline Speed, RPM & $\begin{array}{c}\text { Plane blade, } \\
\%\end{array}$ & \begin{tabular}{c}
$\left(\begin{array}{c}4 \text { teeth/inch }), \\
\%\end{array}\right.$ \\
\hline 200
\end{tabular} $7^{2}$ & $\begin{array}{c}8 \text { teeth/inch), } \\
\%\end{array}$ \\
500 & 75 & 92 & 94 \\
700 & 78 & 96 & 94 \\
1000 & 81 & 96 & 96 \\
\hline
\end{tabular}

Table 2. Current measurements acquired with the datalogger.

\begin{tabular}{cccc}
\hline & \multicolumn{3}{c}{ Measurements during cutting } \\
\hline Variable & $\begin{array}{c}\text { CD blade } \\
\text { (avg.) }\end{array}$ & $\begin{array}{c}\text { Steel blade } \\
\text { (avg.) }\end{array}$ & $\begin{array}{c}\text { Abrasive blade } \\
\text { (avg.) }\end{array}$ \\
\hline Peak current, A & 7.9 & 8 & 7.9 \\
Cutting time, s & 2.5 & 1.4 & 1.1 \\
Acc. current, A & 3 & 1.8 & 1.4 \\
\hline
\end{tabular}

It is important to acknowledge that light motors are required during harvest and test the vibration produced as it can produce wrist damage in workers. Slow speed tools vibrate less than high speed abrasive tools. Abrasive tools can reduce vibration with the use of plastic thin gloves.

Abrasive tools were found more energy efficient and preferred over steel blade tools as the power consumed was less; the battery lasted longer.

For motor control a MOSFET was employed, but in the future a half bridge should be used to recirculate energy to the battery.

\section{Conclusion}

It can be concluded that the harvesting tool consumes different power according to the blade employed. It was found that the abrasive blade was the most energy efficient and did not slash the pear tissue; its use permits that the battery can stand longer. The current integral was very useful in distinguishing the best blade performance and Fourier analysis could also be employed. Toothed steel blades performed better than plane ones for harvesting the pear from the nopal plant. The worst performance was achieved with the compact disc blade due to its poor sharpening and plastic material.

\section{Acknowledgements}

I would like to acknowledge ICAMEX for the funding of the project and to the producer of San Jose Teotihuacan for their help during harvesting.

\section{REFERENCES}

[1] A. P. Vargas, "Perspectiva de Exportación a Francia de la Tuna (Opuntia spp.) Producida en México [France Export Perspective of Prickle Pear (Opuntia spp.) Produced in Mexico]," Tesis de Licenciatura, División de Ciencias Económicas Administrativas, Universidad Autónoma Chapingo, Texcoco, 2002.

[2] J. Ríos and V. Quintana, "Manejo General Del Cultivo Del Nopal [General Management of the Nopal Crop]," Secretaria de la Reforma Agraria, Colegio de Posgraduados, México D.F., 2004.

[3] J. A. Morga, E. N. Aquino and E. M. Silva, "Effect of Controlled Atmosphere on the Preservation of Minimally Processed Cactus Pears," Acta Horticulturae, No. 728, 2006, pp. 211-216.

[4] H. Larson, "OAN Worksite Redesign Project," In: C. Sivesind, Ed., A Clip in Time Saves Nine, Digger, 2001, pp. 54-59.

[5] Felco, "Power-Assisted Pneumatic Tools, Electric Tools, Accessories," Felco, Mélèzes, 2007. http://www.felco.com

[6] S. P. Sonawane, G. P. Sharma and A. C. Pandya, "Design and Development of Power Operated Banana Slicer for small Scale Food Processing Industries," Research in Agricultural Engineering, Vol. 57, No. 4, 2011, pp. 144152.

[7] B. Emadi and P. Yarlagadda, "Peeling Pumpkin Using Rotary Cutter," International Conference on Manufacturing and Management: GCMM-2006, Santos, 19-22 November 2006, pp. 114-118.

[8] W.-C. Lin, "Machine for Cutting and Grinding Fruits, Vegetables and Foods," US Patent No. 0090478, 2012. 